\title{
Experimental Measurements on the Effect of Solar Still Basin Height on its Performance.
}

\author{
Mahmoud Roshdy \\ Dep. of Mechanical Engineering \\ Faculty of Energy Engineering \\ Aswan University \\ Aswan, Egypt
}

engmahmoudroshdy3@gmail.co $m$.

\author{
Salama Abd Elhady \\ Dep. of Mechanical Engineering \\ Faculty of Energy Engineering \\ Aswan University \\ Aswan, Egypt
}

salama_AbedelHady@hotmail.co

\author{
Mohamed Shaban \\ Dep. of Mechanical Engineering \\ Faculty of Energy Engineering \\ Aswan University \\ Aswan, Egypt
}

mshaban68@yahoo.com

\author{
Mohamed Fathy \\ Dep. of Mechanical Engineering \\ Faculty of Energy Engineering \\ Aswan University \\ Aswan, Egypt
}

mfsadik@yahoo.com

\begin{abstract}
Due to water scarcity crisis, many technologies are used to solve these problems, one of these technologies is a single basin solar still, which considers the simplest and cheapest technology. It uses for converting available salt or brackish water into potable water. This paper presents the experimental work conducted on conventional basin type Solar Still to investigate the effect of some design and operating parameters on the performance of the still. In this paper, two single basins are built to study the effect of the glass height from the basin bottom. All conditions of taking the experimental results are taken at the same time. The temperature of ambient, water, vapor and outlet glass are measured from 8.00 to 17.00 of day time every one hour. The productivity of the distilled water and solar intensity are measured as well. The study showed that the productivity increased by $60 \%$ per day when the gap distance between water surface and cover reduced from $26.0 \mathrm{~cm}$ to $6.0 \mathrm{~cm}$ measured from the front (south) wall of the solar still, or (from $37.0 \mathrm{~cm}$ to $17 \mathrm{~cm}$ measured from the center of glass cover) at the same angle $24^{\circ}$ and $2 \mathrm{~cm}$ water depth.
\end{abstract}

Keywords Solar still; Solar distillation; Passive solar still; Operational parameters; Climatic parameters; gap distance.

\section{Introduction}

Solar radiation is the most effective parameter of still productivity. Aswan is one of the most places in Egypt, where has a high solar intensity, so the experiments are performed in it. Many regions of Egypt suffering from water scarcity problems. As a result, the solar distillation would be a suitable solution for freshwater production, i.e. single basin solar still is a good solution to this problem, Single slope solar stills are one of the solar devices which can be used for freshwater production. Solar energy can be used as a source of heat for any distillation process. Processes employing heat can be supplied with steam from boilers heated by concentrated solar energy. Studying the possibility of utilizing solar energy for water distillation has the interest of many researchers.

Many parameters effected on distillation output by solar energy. Adhikari et al.[1] (1995) reported that solar distillation is one of the important and technically viable applications of solar energy. A considerable amount of work has been done for studying basin-type solar stills. The prototype design of such solar stills consists of a blackened water basin having a sloped transparent cover, which permits incident solar radiation to pass through it and gets absorbed by the basin, water gets heated and the water vapors formed condense over the underside of the cover to form droplets which are collected in a trough as distilled water, also they reported that a computer simulation model is presented for studying the steady-state performance of a multi-stage stacked tray solar still. As natural freshwater resources are limited, seawater plays an important part as a source for drinking water as well, to use this water, it has to be desalinated. The desalination method is a process of obtaining pure water from waste / brackish or saline water using solar energy.

According to World Health Organization [2], the permissible limit of salinity in water is $500 \mathrm{ppm}$ and for special cases up to $1000 \mathrm{ppm}$ while most of the water available on earth has the salinity up to $10,000 \mathrm{ppm}$ whereas seawater normally has salinity in the range of 35,000-45,000 ppm in the form of total dissolved salts. Bilal et al. [3] studied the effect of the salinity of water on solar distillation. The results show that as the salt concentration increases in the water, the production rate decreases due to the increase in the partial pressure of the salt in the water solution. Ghandour [4] studied the effect of salinity level of raw water on the productivity, the experimental results for different concentrations of saline feed water were $5500 \mathrm{ppm}, 10,500$ ppm, $15,500 \mathrm{ppm}$ and $35,000 \mathrm{ppm}$ producing distilled water 500 ppm, 750 ppm, 1200 ppm, and 1890 ppm respectively.

The saline feed water curve and the distilled water curve tacks the same trends of increasing the salinity feed water with increasing the salinity-distilled water. Talaat et al. [5] found that using high salt concentration brackish feeds water increasing the energy consumption of desalination. Low salinity brackish water (TDS $1000 \mathrm{ppm}$ ) consumes $0.40-0.60$ $\mathrm{kWh} / \mathrm{m} 3$, medium salinity brackish water (TDS 1000-3000 ppm) consumes $0.80-2 \mathrm{kWh} / \mathrm{m} 3$ and high salinity brackish water (TDS 3000-5000 ppm) consumes $2.2-3.3 \mathrm{kWh} / \mathrm{m} 3$. Desalination processes fall into two main categories, thermal processes or membrane processes, thermal processes are generally used in the following applications: to treat highly saline waters (predominantly seawater), where large volumes of produced water are required. In locations where energy costs are low or where a waste heat source is available. On the other hand, membrane processes are more favorable for treating brackish waters (under most conditions) or highly saline wastes where energy costs are high or the flow rates are low.

Many theoretical and experimental studies have been done on single slope solar stills. The effect of solar radiation on productivity has been investigated in many publications. It is found that solar radiation is the most affecting parameteraon 
still productivity. [6] The choosing of the cover tilt angle is an important factor. The trend obtained suggests an optimum cover tilt angle that is close to the latitude angle of the site [7]. There is a gap between the surface of the water and a condensing cover in the still system, and reducing this gap will increase the performance of the stills. It is also speculated that the influence of the distance of the gap is profoundly more significant compared to the influence of the cover tilt angle. [8]. Ghoneyem [8] put this improvement in numbers; in his work, he reduced the gap between the water surface and cover from $13.0 \mathrm{~cm}$ to $8 \mathrm{~cm}$, which resulted in an increase of $11 \%$ in terms of daily productivities.

In the present work, tow solar stills were studied, the first has a high gap distance between the glass and basin, and the other has a low gap distance. The results are shown that when the gap between the water surface and cover reduced from $26.0 \mathrm{~cm}$ to $6.0 \mathrm{~cm}$, daily productivity increased by $60 \%$.

\section{EXPERIMENTAL SETUP}

In this work, tow conventional single slope solar stills are designed and fabricated for the desalination of Mediterranean water, the tow stills have been constructed from a plank of wood as shown in Fig. 1.

Table 1: Technical specifications of the solar still.

\begin{tabular}{|c|c|}
\hline Specification & Dimensions \\
\hline Basin area, $\mathrm{m}^{2}$ & .258 \\
\hline Glass area, $\mathrm{m}^{2}$ & .278 \\
\hline Glass thickness, $\mathrm{mm}$ & 3 \\
\hline Number of glass & 1 \\
\hline $\begin{array}{c}\text { The tilt angle of the glass } \\
\text { cover }\end{array}$ & $24^{\circ}$ \\
\hline
\end{tabular}

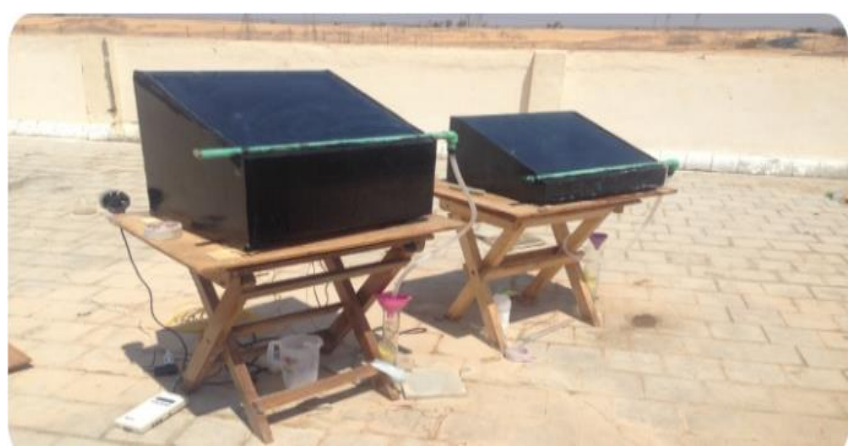

Fig. 1. Photo of the tow stills.

The selected materials have generally been based on knowledge of the conditions prevailing in various parts of solar still and an assessment of the material cost and ease of incorporating it in construction. The technical specifications of the solar still shown in Table1, and the schematic diagram of a single basin type solar still was shown in Fig.(2).

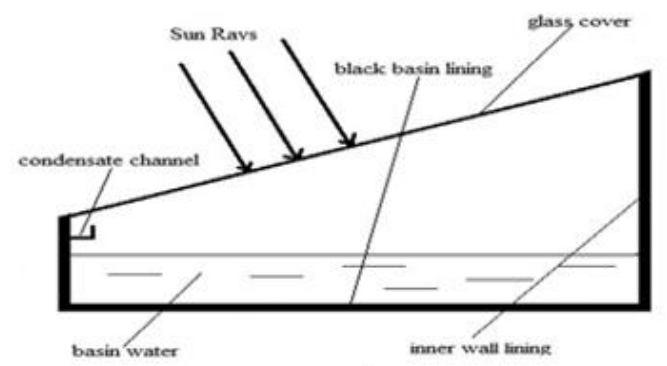

Fig.2.Schematic diagram of a single basin type solar still [9]

\section{A. Basin}

The basin was made from wood and painted with a black absorptive substance, $1.25 \mathrm{~mm}$ in thickness. The high gap distance still basin liner area is $0.258 \mathrm{~m} 2$, and one side height is $30 \mathrm{~cm}$ and the other side is $52.26 \mathrm{~cm}$. For the low gap distance still, one side is $10 \mathrm{~cm}$, and the other side is $32.26 \mathrm{~cm}$, and the tow stills have a tilt angle of $24^{\circ}$.

\section{B. Basin liner}

This is the major part of the solar still. It absorbs the incident radiation that is transmitted through the glass cover. Basin liners were used to increase the absorptivity, such as black stones and normal no glossy black paint. In this work, the basin liner made of wood which painted with a black silicon liner of $56 \times 46 \mathrm{~cm}$.

\section{Glass cover}

In this work, a window glass of $3 \mathrm{~mm}$ thickness was used, its average transmissivity $(\mathrm{t})$ is 0.87 , and it was positioned at an angel $24^{\circ}$ to the horizontal axis. A glass cover has been sealed with silicone rubber, which is the most successful because it will make strongly contact between the glass and many other materials. The sealant is important for efficient operation.

\section{Insulation materials}

The insulating coated is used to reduce the heat losses from the bottom and the sidewalls of the solar still in this work. The insulating cover is a black coated of $4 \mathrm{~mm}$ thickness.

\section{E. The distillate channel}

The distillate channel is used to collect the condensate from the lower edge of the glass cover and carry it to the storage bottle; it was made of the Poly Vinyl Chloride (PVC) materials of $(\mathrm{V})$ shape.

\section{F. $\quad$ Measuring device}

1. Solar Radiation: In the present study a Pyranometer (Kipp \& Zonen CMP3) is used to measure the solar radiation, this device measures the instantaneous intensity of radiation in $(\mathrm{W} / \mathrm{m} 2)$ (its range is from 0 to $2000 \mathrm{~W} / \mathrm{m} 2$ and the accuracy is $\pm 10 \%)$.

2. Temperature: The temperature at various locations in the still were measured by thermocouples (type-k) coupled to a digital thermometer (its range is from -50 to $1500^{\circ} \mathrm{C}$ ), the accuracy of this device is $0.3^{\circ} \mathrm{C}$ for the temperature measurements between 1 and $99^{\circ} \mathrm{C}$. Four thermocouples probe were used to measure the temperature of the following items: Vapor, water, and outlet glass cover. An external thermometer is used to measure the ambient temperature. 
3. Distilled water: Distilled water was measured by a beaker with a maximum range of $1000 \mathrm{ml}$ and $\pm 2 \mathrm{ml}$ accuracy.

\section{EXPERIMENTAL PROCEDURE}

The two stills partially filled with seawater with a height of $2 \mathrm{~cm}$, the aim of this work to study the effect of the gap distance of the solar still. Both of them faced the south direction all day, with a tilt angle of $24^{\circ} \mathrm{c}$. The experiments were carried out on the three days of September 2019; hourly measurements were made from sunshine to sunset during the trial period and the average of results was taken for these days.

\section{RESULTS AND DISCUSSIONS}

This section will present the influence of different conditions on the productivity of the solar still. Different variables were measured hourly such as outer glass temperature $\left(\mathrm{T}_{\mathrm{g}}\right)$, ambient temperature $\left(\mathrm{T}_{\mathrm{a}}\right)$, water temperature $\left(\mathrm{T}_{\mathrm{w}}\right)$, vapor temperature $\left(\mathrm{T}_{\mathrm{v}}\right)$, solar radiation $(\mathrm{I})$, and productivity $\left(\mathrm{P}_{\mathrm{r}}\right)$.

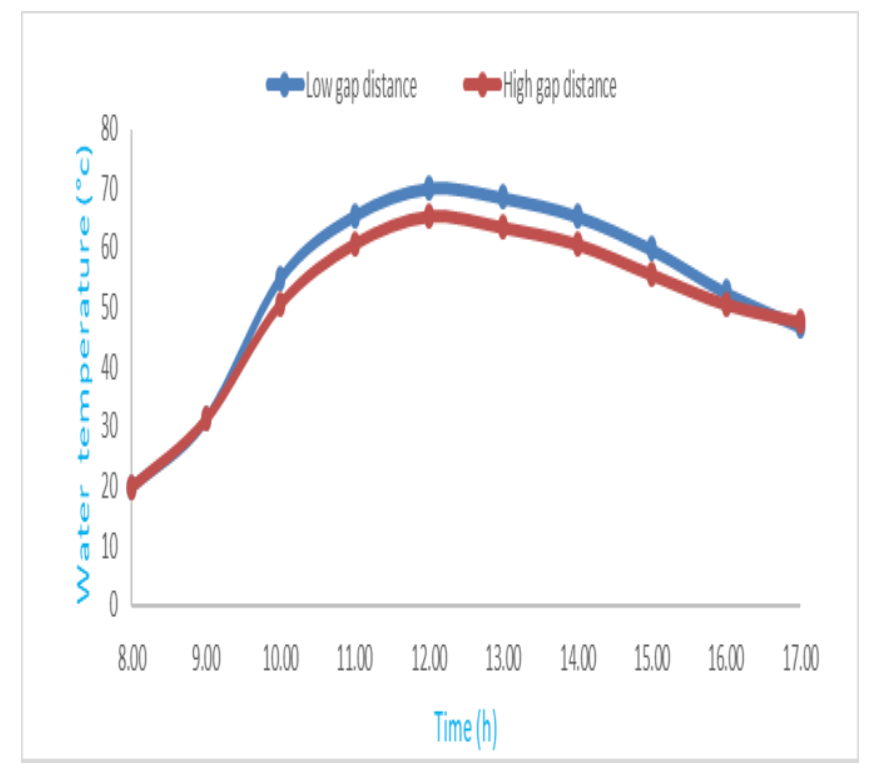

Fig. 3. Water temperature of the tow stills.

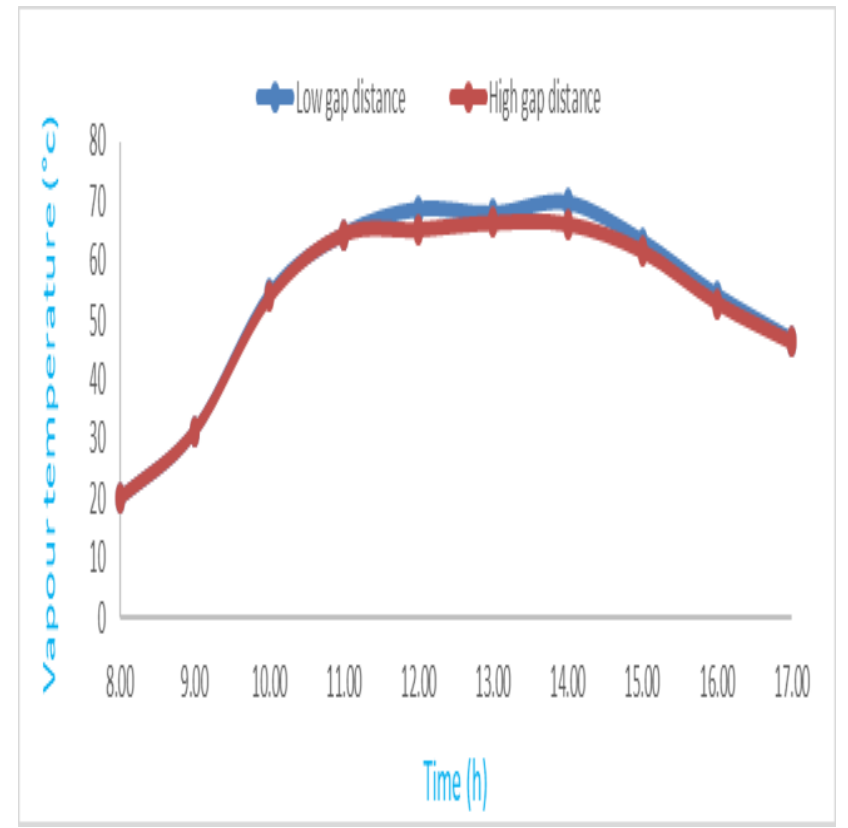

Fig. 4. Vapor temperature of the two stills.

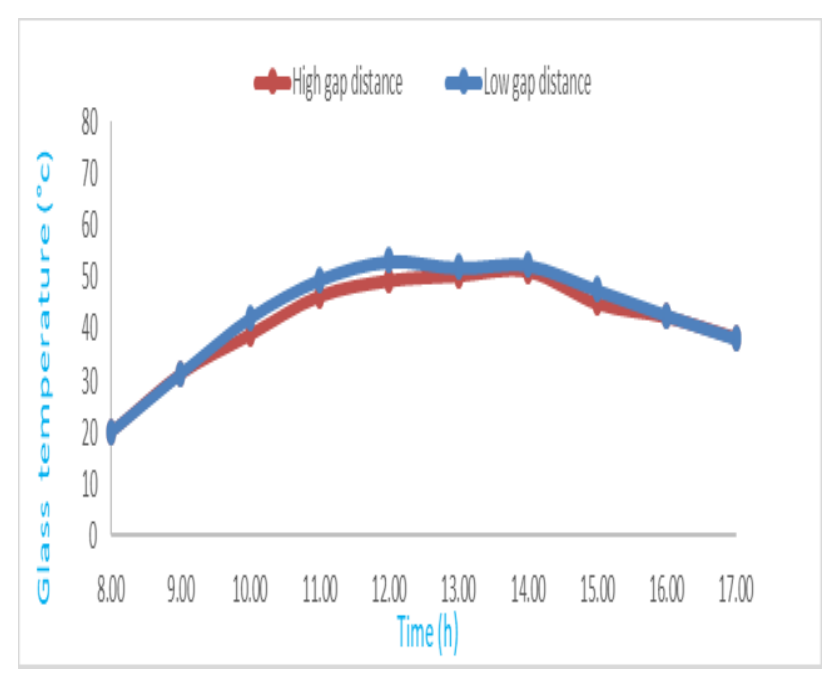

Fig. 5. Glass temperature of the two stills.

Figs. 3-5 show the temperature of the water, vapor, and glass of the two solar stills respectively. The still of low gap distance have slightly higher temperatures than the still of high gap distance. Fig.3. indicates that the water temperature was around $20^{\circ} \mathrm{C}$ in the early morning in the two stills and reaches the maximum temperature at midnight, maximum water temperature in the low gap distance and the high gap distance stills are $70.1^{\circ} \mathrm{C}$ and $65.36^{\circ} \mathrm{C}$ respectively.

Fig.4. shows the variation of the vapor temperatures with time, the maximum vapor temperatures that occur during the period 14.00 are $69.6^{\circ} \mathrm{C}$ and $66.2^{\circ} \mathrm{C}$ for the low gap distance and the high gap distance stills respectively. Fig.5. shows the glass temperature for the two stills, it indicates that the low gap distance still has a glass temperatures more than the high gap distance. 


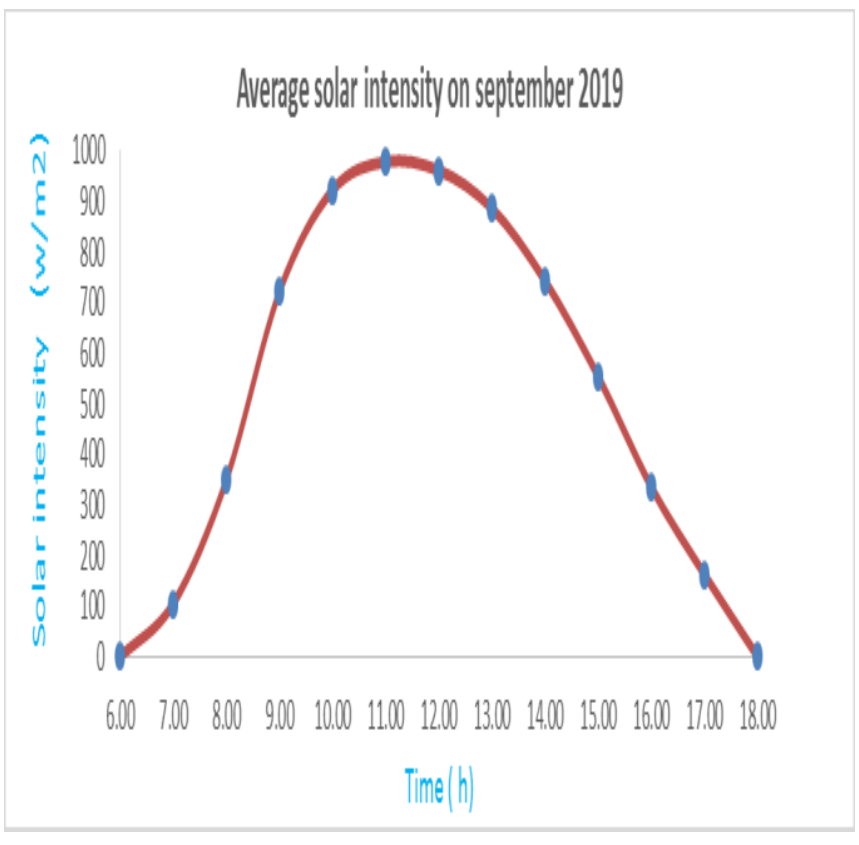

Fig. 6. Relation between the solar intensity and local time.

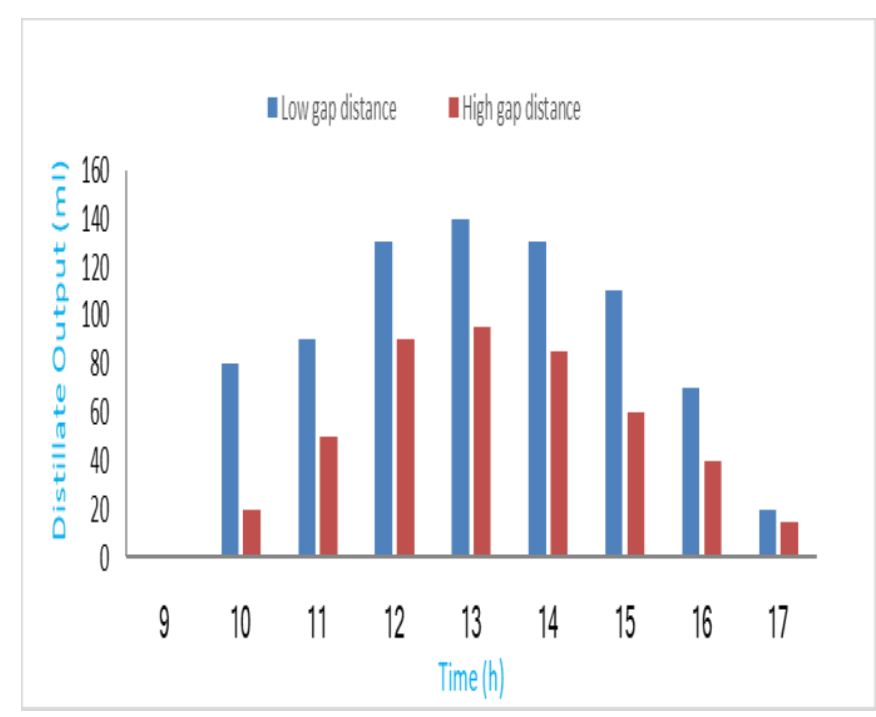

Fig. 7. Collected distilled water of the two stills.

The effect of solar radiation on the productivity for the conducted experiments is shown in Fig.6. and Fig.7. the maximum yield occurs during the period from 12:00 to 13:00 corresponding to higher solar radiation, also Fig.6. shows that the solar radiation increases and reaching its maximum value of $980 \mathrm{w} / \mathrm{m} 2$ at noon (11.00), then it decreases gradually. These figures indicate that the effect of solar radiation intensity on still productivity is pronounced. Fig.7.shows the accumulated distilled water of the two stills. The productivity of the low gap distance still is more than the high gap distance by about $60 \%$, this due to the vapor of the high gap still consumes some of solar energy in increasing its pumping up to surface instead of increasing the productivity process. Reducing the gap distance will reduce the height of the walls of the cover slope and hence will reduce the shadowing effect of these sides and this may help in the productivity increasing process. Also, less time is elapsed by the saturated air to reach the condensing surface and therefore, continuous and quicker air movement in the still is occurs.

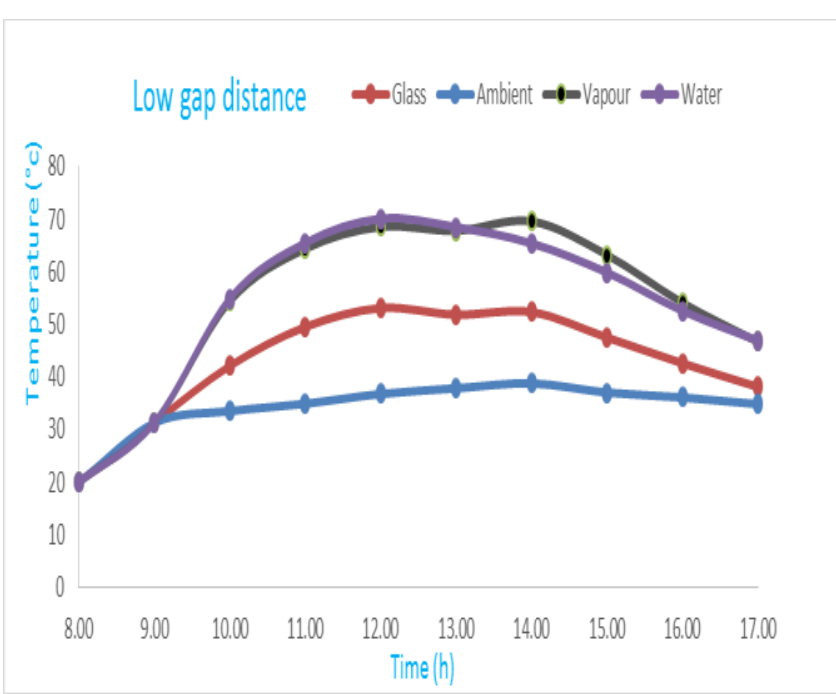

Fig.8. Variations between the temperatures in the still of a low gap distance.

Fig.^. shows that the increase of the water temperatures values is close to the vapor temperatures but, the water temperatures are slightly higher than vapor temperatures until reaching the period 13.00 , then the vapor temperatures increase slightly from 13.00 to 14.00 , and after this, both of them decrease until they reach the same point.

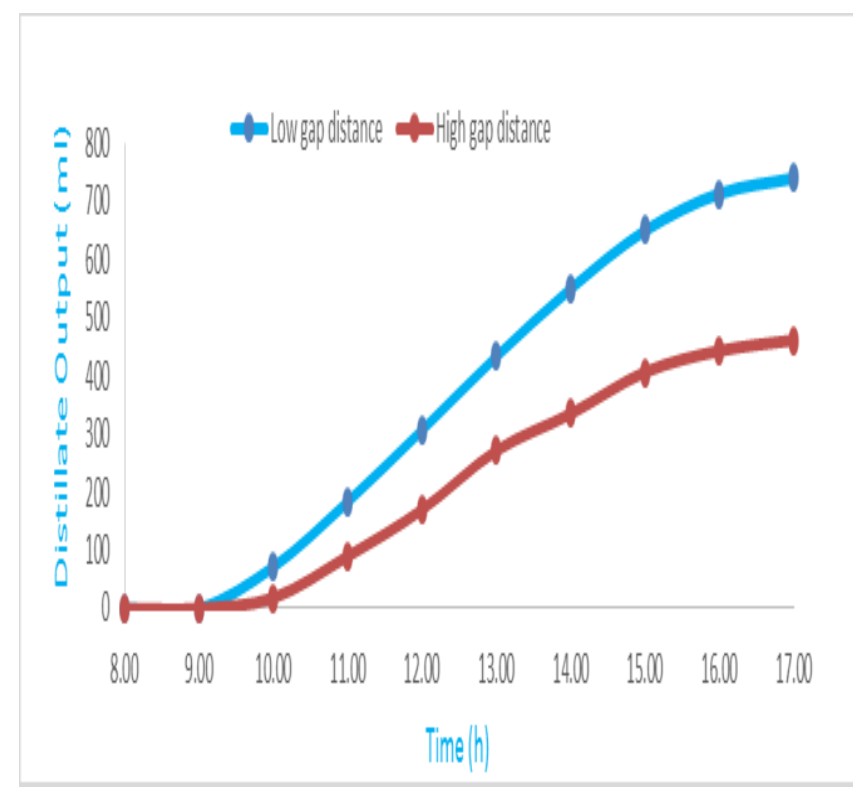

Fig. 9. Comparison of cumulative distillate output for low and high gap distance stills.

Fig. 9. compares the cumulative productivity of the solar still with the tow different gaps. The productivity of the high gap distance still and the low gap distance still is about 462 
$\mathrm{mL}$ and $740 \mathrm{~mL}$ respectively from 8.00 to 17.00 for the basin area of $\left(0.46^{*} 0.56\right) \mathrm{m}^{2}$. It can clearly be observed that reducing the gap improves the distillate yield significantly. This can be attributed to higher rate of convective heat transfer also, as the heated water surface and comparatively cooler glass surface comes closer the rate of distillation increases therefore, an increase in productivity is observed on reducing the gap so, the showed that the low gap distance system increases productivity by about $60 \%$.

\section{CONCLUSIONS}

Single basin solar stills use for converting available salt or brackish water into potable water also, they are cheap and easy to construct, so they have more applications in our life such as industrial processes, Sterilization, and battery maintenance and radiator. Tow solar stills were studied, and the effect of reducing the gap between absorber and condenser cover was experimentally evaluated. It was found that reducing the gap increases daily productivity by $60 \%$. Reducing the gap between absorber and condenser cover increases the convective heat transfer between the water surface and condenser cover. The low gap distance still is more significant than the high gap distance. As the heated water surface and comparatively cooler glass surface comes closer the rate of distillation increases therefore, an increase in productivity is observed on reducing the gap. Reducing the gap distance will reduce the height of the walls of the cover slope and hence will reduce the shadowing effect of these sides. Finally, the gap distance between water surface and cover is reduced from $26.0 \mathrm{~cm}$ to $6.0 \mathrm{~cm}$.

\section{REFERENCES}

[1] Adhikari, R.S.; Kumar, A., and G.D.Sootha (1995). Simulation studies on a multi-stage stacked tray solar still. Solar Energy 154 (5): 317-325.

[2] World Health Organization (WHO), 2004. Guidelines for Drinking-Water Quality,Recommendations, Vol. 1. World Health Organization, Switzerland, Geneva.

[3] Bilal, A.A., Mohsen, M.S.,Nayfeh, W., 2000.

Experimental study of the basin type solar still under local climate conditions. Energy Convers. Manage. 41 (9), $883-890$.

[4] Ghandour, A., 2001. Use of solar energy for water distillation Ph.D. Thesis. Agricultural Engineering Department, Faculty of Agriculture, Zagazig University.

[5] Talaat, H.A., Sorour, M.H., Rahman, N.A., Shaalan, H.F., 2002. Pretreatment of agricultural drainage water for large scale desalination. In: Proceedings of the Euro Med Conference on Desalination Strategies in South Mediterranean Countries, Egypt.

[6] A.S. Nafey, M. Abdelkader, A. Abdelmotalip and A.A. Mabrouk,, "Parameters affecting solar still productivity," Energy Conversion \& Management, vol. 41, pp. 17971809,2000

[7] A. J. N. Khalifa, "On the effect of cover tilt angle of the simple solar still on its productivity," Energy Conversion and Management, vol. 52, pp. 431-436, 2011.

[8] Ghoneyem A. Experimental study on the effects of the cover and numerical prediction of a solar still output [MS thesis]. Ankara: METU; 1995.

[9] Srivastava, P. K., \& Agrawal, S. K. (2012). Experimental investigation of some design and operating parameters of basin type solar still. International Journal of Emerging Technology and Advanced Engineering, 2(5), 225-230.

[10] H. Al-Hinai, M.S. Al-Nassir, B.A. Jubran, Effect of climatic, design and operational parameters on the yield of a simple solar still, , Journal of Energy Conversion \& Management, 43 (2002) 1639-1650.

[11] H. Al-Hinai, M.S. Al-Nassir, B.A. Jubran, Parametric investigation of a double-effect solar still in comparison with a single-effect solar still, Desalination 150 (2002) 75-83.

[12] A.A. Al-Karaghouli, W.E. Alnaser, Experimental comparative study of the performances of single and double basin solar-stills, Appl. Energy 77 (2004) 317325 .

[13] V. Velmurugan, M. Gopalakrishnan, R. Raghu, K. Srithar, Single basin solar still with fin for enhancing productivity, Journal of Energy Conversion \& Management, 49 (2008) 2602-2608.

[14] G.N. Tiwari, H.P. Madhuri, Garg, Effect of water flow over the glass cover of a single basin solar still with an intermittent flow of waste hot water in the basin, Journal of Energy Conversion \& Management,. 25 (1985) 315-322.

[15] Bilal A. Akash, Mousa S. Mohsen, Omar Osta, Yaser Elayan, Experimental evaluation of a single-basin solar still using different absorbing materials, Journal of Renewable Energy 14 (1998) 307-310.

[16] M.A. Samee, U.K. Mirza, T. Majeed, N. Ahmad, Design and performance of a single basin solar still, Renew. Sustain Energy Rev. 11 (2007) 543-549. 